\title{
Testing the models of transition in practice: the case-studies of Estonia and Slovenia
}

\author{
Testando os modelos de transição na prática: \\ os casos da Estônia e da Eslovênia
}

VILJAR VEEBEL

ANDRA NAMM*

RESUMO: O presente estudo baseia-se na comparação dos verdadeiros processos de transição na Estônia e na Eslovênia, em 1991-2000, com o objetivo de testar dois modelos conceituais (terapia de choque versus gradualismo) da teoria da transição na prática. Este artigo tem dois objetivos principais, estreitamente interligados. A primeira tarefa é analisar se os caminhos de reforma adotados pela Estônia e pela Eslovênia seguiram os conceitos teóricos da "terapia de choque" e "gradualismo", os modelos dos estados muitas vezes simbolizados em debates teóricos. A segunda tarefa é avaliar a capacidade dos modelos teóricos para alocar corretamente os exemplos clássicos de países para modelos de terapia de choque e gradualistas. Esta pesquisa procura mostrar quais são as vantagens e as desvantagens de uma abordagem polarizada para modelos de teoria de transição e como esses modelos podem ser melhorados.

PALAVRAS-CHAVE: Estônia; Eslovênia; modelos de transição.

ABSTRACT: The following study is based on the comparison of the actual transition processes in Estonia and Slovenia in 1991-2000 with the aim of testing two conceptual models (shock therapy versus gradualism) of transition theory in practice. This article has two main goals, closely interlinked with each other. The first task is to analyse whether the reform paths undertaken by Estonia and Slovenia followed the theoretical concepts of 'shock therapy' and 'gradualism', the models the states are often symbolising in theoretical debates. The second task is to evaluate the ability of the theoretical models to correctly allocate the classical country examples to the shock therapy and gradualist models. This research study is also interested in what are the advantages and disadvantages of a polarised approach to transition theory models and how these models can be improved.

KEYWORDS: Estonia; Slovenia; models of transition.

JEL Classification: E13; E62; H11; I38; O57.

\footnotetext{
* Estonian National Defence College, Chair of Strategic Studies. Address Riia 12-204, Estonian National Defence College, Tartu, Estonia. E-mail: viljar.veebel@ut.ee; University of Tartu, Institute of Governance. E-mail: andra.namm@mail.com. Submitted 19/August/2014; Approved: 7/July 2015.
} 


\section{INTRODUCTION}

The collapse of the Soviet Union (SU), including both the former Soviet republics and its socialist satellites in Central and Eastern Europe (CEE), from Estonia to Slovenia offered a unique challenge and a need for system-wide economic and social transitions. It also offered a possibility of testing and evaluating different theoretical models of transition from radical shock therapy to gradualism in practice. Estonia and Slovenia, while being similar in many aspects (two small states in the CEE, both former members of an authoritarian federal union, both regaining independence in 1991 and both joining the European Union (EU) in 2004), have often symbolised two opposite approaches and reform paths in terms of transition processes, with Estonia representing the shock therapy model and Slovenia representing the gradualist model. This article aims at analysing to what extent the reform paths undertaken in these two countries match the theoretical criteria of the models they are supposed to represent and symbolise.

One may ask, why open this old debate again in the year 2015? The recent Eurozone financial crisis has once again made both countries face choices - whether to achieve fiscal consolidation with the gradual adjustment or with the shock therapy model. History seems to repeat itself, as Estonia has once again selected the model of austerity and shock therapy, while Slovenia has once again opted for gradualism (Veebel and Kulu 2014). Accordingly, existing socio-economic experiences may create path-dependence and form a supportive basis for similar choices in the future, which makes it even more important to research whether Estonia and Slovenia actually were following the transition paths that they have come to symbolise after regaining their independence.

The present research has two central goals, closely interlinked to each other. The first task is to analyse how the reform paths undertaken by Estonian and Slovenia correspond to the theoretical concepts of 'shock therapy' and 'gradualism'. The second task is to evaluate the ability of the theoretical models to correctly allocate the classical country examples to the shock therapy and gradualist models and offer suggestions to improve existing theoretical approaches. This research study is also interested in which are the advantages and disadvantages of the polarised approach to transition theory models.

Following research is also important as it focuses on the varieties of successful modernisation and democratisation models in the small states of CEE, which produces the basis of experience needed for the next wave of transition countries and helps to adjust the existing theoretical models.

\section{THEORETICAL DEBATE: MODELS OF TRANSITION}

The 'models of transition' framework has been the dominant theoretical and analytical approach used in 1991-2010 to analyse the transition processes in the CEE (Balcerowicz, 1995; Dewatripont and Roland, 1992; Lipton and Sachs, 1990; 
Marangos, 2005b). The main strength of this framework is in providing readers with a simple conceptual axis that they can use to compare and contrast the countries in the transition process. This practical separation of opinion into two opposing schools of thought has influenced a similar separation of academic opinion into (at least) two opposing schools of thought. Following this inertia, the academic 'models of transition' framework attempts to group various transitioning countries together on the basis of similarities in how they reformed key elements of their economy. These models can be lined up linearly on an axis, with the quickest reformers on the one extreme and the slowest reformers on the other extreme.

Speed was the main variable differentiating the two models. Shock therapy supporters believed reforms should be implemented as fast as possible (Balcerowicz, 1995; Lipton and Sachs, 1990). Lipton and Sachs, two leading theorists in support of shock therapy, argued that reform in one area would support the effectiveness of reform in another area in an interactive manner (Lipton and Sachs, 1990, p. 99). This provided them with a theoretical basis that would show shock therapy to be more effective than gradualism. Gradualism was developed as a criticism of the shock therapy model and believed that the sequencing of reforms and slower implementation would be more beneficial for the country in transition. In parallel, an actual active transition process in the CEE was already gaining speed in 1989-1991 and was contributing both in terms of terminology and 'best practices'.

The importance of the current study becomes also evident if we pay attention to the way the transition model correlates with the overall economic development and freedom. Estonia, while starting from considerably low GDP per capita level (10 000 USD, PPP in 1995; earlier data is not available), has in 2013 reached an almost equal development level with Slovenia that had started from the level of 18 000 USD PPP p.c. in 1995. In terms of economic freedom (based on Fraser Economic Freedom Index), Estonia ranks in $22^{\text {nd }}$ position out of 152 countries in 2012, with 7.61 points (out of 10 points), fairly close to the US, scoring 7.81 points. Slovenia ranks in $105^{\text {th }}$ position out of 152 countries in year 2012, with 6.57 points, similar to Russia scoring 6.65 points (Gwartney, Lawson and Hall, 2012). Both countries had reached similar scores also in 1995, namely Estonia 5.80 points and Slovenia 5.00 points; hence, both countries were and still are, seemingly, on different roads.

A major step forward in the evolution of transition framework models was taken by John Marangos, who developed five different models of transitions, incorporating a political dimension in the reforms, as well as making at least a passing reference to the importance of institutional reform. Marangos' models of transitions were based on the excessive oversimplifications created by the previous models (Marangos, 2005b). Marangos tried to bring more variety but also more simplicity into the debate by creating his so-called primary and secondary elements of transition to incorporate political aspects alongside economic ones.

Actual experiences from the CEE, however, did not find sufficient reflection in Marangos' model. As a result, his criteria in some categories were either oversimplified or the benchmarks were set to be so demanding (e.g., privatisation speed and 
scope or liberalisation of salaries) that they were not met by any of the CEE states during their first decade of transition. From a critical perspective, the transition models of Marangos do not fully match the criteria of a proper 'theoretical model', as they are mainly based on the generalization of previous empirical cases and are offering merely the criteria for classification and based on historical transition experience. These models need further development in terms of causality and the ability of differentiation in order to be applicable for socio-economically comparable case studies.

Based on socio-economic variables, Marangos classified five different transition models: 1) the shock therapy transition model; 2) the neoclassical gradualist model; 3) the post-Keynesian transition model; 4) the pluralist market socialist transition model; 5) the non-pluralistic market socialist model. These five models are an amalgamation of "three different views of economic analysis, two different speeds of implementing the reforms and two different political structures" (Marangos, 2005b, p. 308). The models are differentiated by specific elements (criteria) of reforms (e.g., privatisation). The following research will focus on testing models one (the shock therapy transition model) and two (the neoclassical gradualist model).

The shock therapy model is advocating the immediate implementation of the necessary reforms to establish a free market economy (Marangos, 2007, p. 89). Marangos' definition of shock therapy lists 16 different reforms that need to be completed to transform the state into a capitalist one. These reforms are divided into seven subcategories: 1) decisive and full price liberalisation; 2) fast privatisation; 3) gradual institutional development; 4) strict monetary policy; 5) balanced fiscal policy; 6) liberalised international trade; and 7) limited social policy and social security.

Under the decisive and fast liberalisation of state controls on prices, the shock therapy model argues that all controls for prices should be removed within the first year. Income policy (i.e., wage controls and minimum wages) should be liberal during the whole period.

Privatisation of all state companies should be started and finished within year one. A mixture of methods should be used to facilitate speedy privatisation, including: a) restitution, returning the property to the rightful previous owner from the time prior to collectivization; b) auctions, selling to highest bidder; and c) vouchers and free distribution of shares to workers.

Broad ranges of institutions have to be established in order for the transition to proceed smoothly. Initially, these include taxes and a regulatory and legal framework to govern business life, such as contract, private property, and trade law. Halfway through the transition, institutional reforms should also be carried out by strengthening competition policy, bankruptcy law, corporate governance, and the wider regulation of finance and the infrastructure. The shock therapy model advocates for these institutions to be developed gradually by market forces as opposed to being state-driven.

Monetary policy should establish an independent central bank during year one. Hard budget constraints should be used from year one. If a government owned or 
private company faces a crisis, then the government should not bail them out (Marangos, 2006, p. 144).

Fiscal policy should ensure that budget deficits are reduced and year one sees the replacement of corporate taxes by VAT and a flat-rate income tax. A pegged exchange rate should be switched to a floating exchange rate after 1-2 years. International trade should be as liberal as possible, whereas all tariffs and quotas should be removed within two years.

The social policy needs to offer a limited safety net to those who temporarily cannot participate in the job market, and benefits should be short-term. Welfare and other social services should be provided by a mixture of public and private providers.

The gradualist model has the central idea "to establish economic, institutional, political and ideological structures before any attempt at liberalization. These were needed in order to be able to build a competitive market capitalist system in a stable and secure fashion for society that did not create too much disorder" (Marangos, 2005a, p. 264).

Gradualist model lists 17 central reforms, which are further divided into seven subcategories: 1) gradual and limited price liberalisation; 2) slow and gradual privatisation; 3) gradual and natural institutional development; 4) gradual and balanced monetary policy; 5) balanced and neutral fiscal policy; 6) slow liberalisation of international trade; 7) social policy with a large safety net.

Prices should be controlled in the beginning of the transition for about seven years before liberalisation. Wage regulations should be removed by the $10^{\text {th }}$ year of transition. Gradual privatisation should be exercised primarily through the public auction method. Institutions regulating market relations should be developed in an organic, voluntary manner by a joint effort between market and state forces. Monetary policy should establish hard budget constraints and an independent central bank during year three. Fiscal policy should ensure that budget deficits are reduced and year two sees the replacement of corporate taxes by VAT and a flat-rate income tax. A floating exchange rate should be established in year 9. Trade tariffs should be supported during the first eight years of the transition and reduced thereafter. Conditional foreign aid should be used during the whole transition process. A social policy with the medium-wide social safety net has to be available for all groups but for a limited time. Private providers should join in providing welfare services from the third year of transition.

\section{THE METHODOLOGY, CRITERIA AND TEST CASES}

The test cases, Estonia and Slovenia in the period of 1991-2000, were chosen based on their reputations as being the symbolic countries to represent the following transition models. Slovenia has been debated within the framework of a gradualist approach by Mencinger, Roland and Marangos (Mencinger, 2004, pp. 67-83; Roland, 2000, p. 14; Marangos, 2005a, p. 287). Estonia is seen as representing the 
shock therapy model by White and Sachs (White, 2007, p. 57; Sachs, 1995, p. 11). Slovenia and Estonia have not only been considered the extreme cases, but also the success stories (Slovenia until 2008) of the transition process. Something both cases also had in common, was the need to start reforms as a member of an authoritarian federal state, which set numerous special limitations to the speed and scope of actual reform packages. Of course, in many aspects Estonia and Slovenia had different socio-economic starting points in 1991, as Slovenia was an open economy with a functioning product market and a functioning though rather specific labour market before the transition, while Estonia was a part of the Soviet Union's planned economy.

A 10-year timeframe for the test period is chosen according to the suggestion of Marangos, who states that his models have a 10-year timeframe to describe and illustrate the sequencing of reforms. Even if in many aspects reform were conducted faster than 10 years, analysis follows the traditional time frames proposed by models of shock therapy and gradualism.

The criteria and elements to test whether Estonia and Slovenia represent the ideals of theoretical models were developed based on central components of the shock therapy model and the gradualist model. By combining the studies of Sachs (1995), Stiglitz (2002), Dewatripont and Roland (1992) and Marangos (2002, 2006, 2007), specific elements of reforms for evaluation and testing were selected.

The evaluation model is qualitative, each reform element is compared to its ideal model and to its opposite model (i.e., the null hypothesis), and the judgment is made as to whether the case: a) follows the model fully or closely; b) deviates slightly from the model (i.e., if $25 \%-50 \%$ of the model's prescriptions have been contravened); or c) deviates significantly from the model (i.e., if more than $50 \%$ of the prescriptions have been contravened).

The assessment will be conducted with combined methodology where, first, a quantitative analysis will calculate the existence and duration of actual reforms conducted in test countries and, second, a qualitative analysis will evaluate in which level reforms in test countries matched the descriptions of ideal models and opposite models.

In qualitative analysis, the first level analysis score will reflect to what degree the empirical case under study matches the theoretical model in comparison. The second level analysis 'percentage match to the model' score will be calculated based on alternative weights for each of the three categories. Significant deviations are given a small weight of $25 \%$. Slight deviations are discounted at $62.5 \%$, and matches are weighted at $87.5 \%$.

The third level analysis will be performed on 14 reform elements. Each reform element is rated independently by asking: does this reform element correctly identify that Estonia looks more like shock therapy, and Slovenia more like gradualism? $($ scored +1$)$, or does this reform element make Estonia look more like gradualism and Slovenia more like shock therapy? (scored -1). In each calculation level, two types of results will be calculated: first, in which level the reform paths undertaken by Estonia and Slovenia followed the theoretical concepts of 'shock therapy' and 
'gradualism', the models they are supposed to symbolise in theoretical debates. Second, evaluating the ability of the theoretical models to correctly diversify the classical country examples to the shock therapy and gradualist models.

\section{ESTONIA'S CHOICES OF TRANSITION: HOW CLOSE TO THE SHOCK THERAPY MODEL?}

In case of Estonia, seven categories of reforms were analysed: 1) decisive and full price liberalisation; 2) fast privatisation; 3) gradual institutional development; 4) strict monetary policy; 5) balanced fiscal policy; 6) liberalised international trade; and 7) limited social policy.

Marangos' shock therapy model expects the removal of all controls and regulations on prices within the first year of transition. Wages should be driven by market forces, as opposed to being set by the state. Marangos' explanations do not define measurable criteria for market-driven wage policy. In its radical form, it could mean the absence of all wage controls, including the removal of minimum wages, even if most of the transition countries kept some legal minimum wage levels. Therefore, a more practical definition for testing would be the removal of complex wage controls and the establishment of a relatively low minimum wage (i.e., less than $40 \%$ of the average median wage). Estonia started its first steps towards price liberalisation in 1989, when prices on many products were allowed to float (Staehr, 2004, p. 41). By the first half of 1992, the majority of price liberalisation had been completed (Gillies, Leimann, and Peterson, 2002, p. 178; Brown, 1993, pp. 494-495; De Melo, Denizer, Gelb, Tenev, and Tenev, 1996, p. 38). A year later, only publicly provided housing, electricity and heating prices were controlled by the state (Staehr, 2004, p. 44). Therefore, by 1992 most of the price liberalisation reform was completed. European Bank for Reconstruction and Development (EBRD) data suggests that Estonia liberalised prices fully already by 1993 (European Bank for Reconstruction and Development (EBRD), 2003). To summarise, price liberalisation took approximately 3-4 years to complete, marking a slight deviation from the 1-year prescription of the shock therapy model.

In terms of wage policy, Estonia followed the shock therapy model closely. State-directed wage decrees were removed within the first year. The minimum wage was lowered from $37 \%$ of the average wage in 1992 to $25 \%$ of the average wage in 1995 . Thereafter, the minimum wage was slowly raised to $29 \%$ by 2002 (Hinnosaar, 2003, p. 329). In comparative terms, Estonia's minimum wage was among the lowest of all the transitioning countries, low enough for it to remain practically irrelevant at the time of high inflation in 1993-1995 (Noorkõiv, Orazem, Puur and Vodopivec, 1997, p. 21). Even by 1999, EBRD was still commenting that Wages had very little regulation. Although the minimum wage was set, no real wage regulation existed in 1999 (EBRD, 1999, p. 216). Therefore, Estonia's wage liberalisation policy closely followed the shock therapy model.

In terms of privatisation, speed is seen as a more important variable than the 
scope and specific methods used during privatisation. Restitution, auctions and vouchers could all be used, provided that the process aims to finish within 12 months. In Estonia, the privatisation process took much longer, approximately 5-7 years (1992-1996-1998), to reach the criteria of 90\% of non-infrastructure companies being privatised (Terk, 2000, p. 158). This is reflected in EBRD data, which gives a maximum rating of 4.3 for small-scale privatisation by 1996 (EBRD, 1998, p. 216). Large-scale privatisation never reached their 4.3 criterion (EBRD Transition Report, 2005, p. 128). This may again be related to the treatment of infrastructure or utility companies, as the Estonian state continued to administer the Tallinn Harbour and the national electricity company (Staehr, 2004, p. 40). This analysis shows that 1998 marks the end of large-scale privatisation and large-scale asset transfer, as after this year the number and size of deals fell significantly, culminating with the closure of the Estonian Privatisation Agency three years later. To conclude, first level privatisation was relatively rapid and overwhelming, taking just four years to complete. However, the final stage of privatisation was relatively gradual, taking 6 years to complete. As these two phases were staggered over a 7-year period, it is difficult to view the privatisation process as 'rapid', when compared to the 1-year criterion used in shock therapy and, therefore, the example differs significantly from the theoretical model. Evaluating whether the privatisation process in Estonia was fast enough to be classified as shock therapy is the most problematic issue. The conclusions in terms of privatisation depend on the reference basis - whether Estonia is compared with the rest of the CEE reformers or whether its ability is be matched with Marangos' criteria. While Estonia was one of the most radical in terms of privatisation speed and scope in the CEE, it did not meet the shock therapy criteria of Marangos' concept. Accordingly, it is the authors' opinion that in this aspect Marangos' model needs some adjustments, as it is setting excessively high evaluation standards for states in the former Soviet bloc.

With regards to the method of transfer, direct sales were the primary method for privatisation and auctioning the second most common one (EBRD, 1998, p. 32). This again deviates from the shock therapy prescription of multiple methods, and therefore the Estonian case is more similar to the gradualist method. The 7-year timescale of privatisation in Estonia also resembles the 8-year timescale in the gradualist model.

However, contrary to the gradualist model wherein restructuration should take place prior to privatisation, restructuration was significantly slower in Estonia. Throughout 1993-2000, EBRD rated Estonia's corporate governance and restructuration as a flat 3.0 with no progress. Only in 2001 was this raised, possibly on account of the upcoming restructuration of the already privatised oil shale companies (Brendow, 2003, p. 308). Therefore, although privatisation in Estonia was more similar to gradualism than shock therapy, both theories deviated significantly from the actual events in Estonia. Estonia can be described as an exemplary country where privatisation happened relatively fast (Terk, 1999, p. 140), 'supporting' the shock therapy model.

The shock therapy model supports the gradual creation of institutions by spon- 
taneous market institutions when the time seems appropriate for the market (Marangos, 2007, p. 108). The state should not intervene, but rather allow the markets to form their own institutions. Estonia's government set up the initial pro-market institutions relatively quickly. Barry Lesser asserts that once the markets had been liberalised, the recognition followed that the government had an increasing role to play in preventing market failures and abuse, and regulating their activity with new institutions (Lesser, 2000, p. 2). Thus, the competition law and policy were introduced already in 1993 (Rindzeviciute, 2004, p. 50). The influence of external bodies on institutional reform continued with the WB and WTO. An Estonian Memorandum of Economic Policies (1992, Point 49) states that "The Government recognises that there are weaknesses in the present institutional framework for monitoring economic developments and evaluating and coordinating policy. To affect rapid improvement, an inter-ministerial commission, which would also include participation by the World Bank, was established in June 1992, reporting to the Prime Minister".

Similarly, the five years of negotiating with the WTO allowed the WTO to advise on several law changes, adopt new laws, and undertake new obligations. It is difficult to disentangle the market influences from the state influences in these instances, as the two had become closely collaborative. In terms of economic industrial relations, Feldmann stresses that "Market-based forces have been pivotal in shaping institutional policy" (Feldmann, 2006, p. 829), such as in shaping the comparatively regressive tax system.

To summarise, formal institutional reform was a large and important part of the Estonian transition. This was shaped partly by market forces, partly by state forces, and partly by international forces. Therefore, it deviates to some extent from the shock therapy model.

The shock therapy model advocates hard budgetary constraints (Marangos, 2007, p. 110). Hobdari, Jones and Mygind (2009) have pointed out how the existence of soft budget constraints on Estonian businesses during 1993-2002 decreased the probability that investment was financially constrained, but there is no consensus on this question. This is an unexpected and positive outcome that represents a slight deviation from the shock therapy model. Hard budget constraints were imposed on the public sector and private enterprises, and a 'no bailout' policy was enforced for financial institutions (Elenurm, 2004, p. 370). Therefore, it is possible that these predominantly hard budget constraints were in effect throughout most of the transition. This deviates slightly from the shock therapy model, as well as the gradualist model, which both advocated hard constraints from the $1^{\text {st }}$ and $3^{\text {rd }}$ year onwards, respectively.

While the Bank of Estonia, the central bank of the republic of Estonia, was established in 1989, it gained its formal independence only in 1993 (Staehr, 2004, p. 50), when the national currency was introduced. Even if partial independence a year earlier were acceptable, it still would not fully meet the criteria of Marangos. In summary, analysis shows that Estonia deviated significantly from the shock therapy model of central banking. 
In terms of fiscal and tax policy, the shock therapy model advocated for reducing budget deficits, a regressive tax system in which corporate taxes would be replaced by VAT within one year, and a flat-rate income tax level (Marangos, 2007, p. 112). In 1990 and 1991, government budgets were in surplus (Estonian Memorandum of Economic Policies, 1992). Most of this was achieved by maintaining a light state with restraints on taxation and expenditure (Estonian Memorandum of Economic Policies, 1995). During 1999-2001, Estonia experienced a minor budget deficit (3.5\% of GDP), which was neutralised in subsequent years. To summarise, although Estonian governments through the decades have taken the budget deficit issue more seriously than anywhere else in Europe, a short lapse in 1999-2001 marks a slight deviation from the formal shock therapy model.

Estonian tax reform took much longer. At first, Estonia created a progressive income tax system with different tax brackets. This system lasted until 1994 when the flat tax rate was established (Pomerants, 1998, p. 55). A corporate tax was also established, and at first it was progressive but later it was changed to a flat rate of $35 \%$ (Hansson, 1993, p. 8). Therefore, in terms of tax structure, the Estonian example differs significantly from the shock therapy model; in terms of time, it differs due to fluctuations and the limited degree of reform that took place during the transition period.

According to the shock therapy model, international trade should be as liberal and non-regulated as possible. The shock therapy model covers three main areas: the use either of a pegged or fixed exchange rate (as opposed to a floating exchange rate), tariffs, and conditional foreign aid. Initially, a fixed exchange rate is preferred at the beginning of transformation, and after one or two years a flexible rate should be established instead (Marangos, 2007, p. 113). Any restrictions on foreign trade, such as tariffs or quotas, should not exist and be removed within the first two years of transition. For the third domain, conditional foreign aid should be encouraged, and the country should also join the IMF, WB and WTO (Marangos, 2007, pp. 113-114).

Contrary to IMF recommendations, Estonia established its own currency (the kroon) on the $20^{\text {th }}$ of June 1992, making it the first country in Former Soviet Union to do so. The Estonian kroon had a fixed exchange rate pegged to the German deutsche mark, therefore, at no point did Estonia use the flexible exchange rate prescribed in the ideal shock therapy model.

In terms of tariffs, Estonia started to abolish these very early in the transition process. In the first half of 1992, tariffs revenues made up only $1.2 \%$ of government income (Hansson, 1993, p. 4). By 1993, all remaining tariffs were removed and soon thereafter non-tariff restrictions were also removed (EBRD, 1999, p. 214). By 1995 almost all non-tariff restrictions on foreign trade were removed (Estonian Memorandum of Economic Policies, 1995), and Estonia had established "some of the most liberal trade and investment laws to be found anywhere" (Sakkeus, 1998, p. 19).

Reforms went so far that by 2000 Estonia had to re-establish some of its tariffs, in order to be considered for membership of the EU (Rindzeviciute, 2004, p. 44). Therefore, the first 9 years of transition followed the shock therapy model, after 
which post-transition developments forced it to reverse course slightly. However, during the pre-EU accession transition process, Estonia followed the shock therapy model in terms of tariffs almost perfectly.

The shock therapy model expects that a social safety net should be narrow and only created for those who, for whatever reason, cannot participate in the job market. Such aid should be given out only in the short-term, in order to avoid dependence (Marangos, 2002, p. 62). The main social programs in Estonia included extensive maternity leave, child benefits, free education (primary, secondary and, to some degree, tertiary), universal free healthcare, universal pension and disability allowance (Rindzeviciute, 2004, p. 51). The system consists of many different safety nets; however, these are not too generous. For example, the duration of Estonian unemployment benefits in 2000 was 9-12 months, compared to the EU average of 6-60 months. Furthermore, Estonia has notably low minimum wages, unemployment benefits and state pensions. The minimum wage was effectively so low that it never influenced the decisions to hire new people, as effective wages were always higher than minimum wage (Veebel and Loik, 2012).

Moreover, this partial safety net was not put in place within the first year, but was created and reformed many times during the transition period (e.g., unemployment benefits reform in 2002 .

To conclude: out of a total of 15 reform items in Estonia, eight deviated significantly from the shock therapy model, four deviated slightly and three reform items matched the shock therapy model. A corresponding comparison of 16 Estonian reforms using the gradualist model showed that nine reform items deviated significantly, four deviated slightly and three matched the model. This suggests that the Estonian case did not reflect the shock therapy model particularly well, however, did it not reflect the gradualist model particularly well either.

\section{SLOVENIA'S CHOICES OF TRANSITION: HOW CLOSE TO THE GRADUALIST MODEL?}

In the case of Slovenia, where the gradualist model is evaluated, the following reform elements were selected for analysis: 1 ) gradual and limited price and wage liberalisation; 2) slow and gradual privatisation; 3) gradual and natural institutional development; 4) gradual and balanced monetary policy; 5) balanced and neutral fiscal policy; 6) gradual liberalisation of international trade and foreign aid; and 7) social policy with a large safety network.

The neoclassical gradualist model suggests that prices should be controlled by the state at the beginning of the transition for about seven years, after which time the state should gradually start to remove controls over prices (Marangos, 2006, p. 141). At the beginning of transition, prices for basic food, energy and utilities definitely have to be controlled by the state (Marangos, 2005a, p. 269). Marangos' model suggests that this should happen within two years, more precisely from years 7 to 9 after the start of the transition. In terms of wage regulation, gradualists sup- 
ported wage controls during the first nine years of the transition, after which the market should slowly step in and determine wage levels without state interference (Marangos, 2005a, p. 270).

Slovenia began its price liberalisation before the start of the official transition (Avolio, 1995, p. 3). In 1987, about 40\% of prices had been liberalised. Slovenia then liberalised most of its prices between 1988 and 1989 (Sachs and Pleskovic, 1994, pp. 196-197). However, when Slovenia began its work towards being accepted as a future EU Member State in 1997, it had to further liberalise its prices, as its previous efforts were not seen as being extensive enough. EBRD summarised how state-controlled prices still accounted for $28 \%$ of the retail price index and $20 \%$ of the consumer price index (EBRD, 1998, p. 190). This suggests that Slovenia had liberalised most of its prices by 1989 , but about a quarter remained under state control until 1997. This deviates significantly from the gradualist prescription.

In terms of wage policy, Slovenia froze its nominal wages for six months at the start of the transition program, signalling its tendency to regulate wages in the future. A series of reports by the EBRD between 1998-2004 indicate that wage regulations still took place in Slovenia during the first 9 years of transition (as per the model) but also in the years thereafter (slight deviation from the model) (EBRD, 2004, p. 180).

Gradualists support slow and gradual privatisation over approximately eight years; this is achieved by way of auctions that sell assets to the highest bidder (Marangos, 2006, p. 143). Selling of small and medium size companies should be done quickly, during the third year of the transition, and should be completed within 12 months. Before the privatisation of large enterprises, such companies should first be restructured within the first 3-9 years of the transition process (Marangos, 2005a, p. 275). After restructuring, each large enterprise should be sold. The entire process should be finished within one year by the end of year ten (Marangos, 2005a, p. 285).

The privatisation process had already begun under Yugoslavia, when the first privatisation laws were passed that allowed companies to transfer capital to private hands (Smith, Cin and Vodopivec, 1997, p. 163). Slovenia used two different privatisation methods: with small and medium sized companies, internal buyout was the preferred method, while bigger companies combined public auctions with the internal distribution of shares (Mencinger, 2006, p. 10). This mix of methods means that Slovenia did not follow the neoclassical gradualist prescription of preferring the auction method for all enterprises.

EBRD data (EBRD 1999) confirms that small enterprise privatisation had already begun before the official transition period. In 1989, Slovenia had already received a rating of 3.0 ("substantial share privatised and comprehensive program almost ready for implementation”). This predates the gradualist prescription by 4 years. Small-scale privatisation reached 4.0 ("complete privatisation of small companies”) by 1993 according to the EBRD data (EBRD 1999). Therefore, small-scale privatisation took a total of 5 years, significantly longer than the 1 year suggested by the model. 
In terms of large enterprises, initial sales began already in 1993 (EBRD rating $2.0)$. By $1997,25 \%$ had been sold, but "possibly with major unresolved issues regarding corporate governance" (rating 3.0) (EBRD, 1999). The rating had not increased by 2012, suggesting that large-scale privatisation is still incomplete. Accordingly, there is a significant deviation from the model in starting the process 7 years earlier and in not finishing the process quickly. In terms of restructuring companies prior to privatisation, this too was minimal (Hannula, 2000). This suggests that significant restructuration took place in the 1997-2000 period; at least three years after large-scale privatisation began.

When it comes to these criteria, the authors oppose Marangos' logic, which is supported by the Slovenian experience, since on the one hand it is not logical to expect privatisation of large companies during one year, and on the other hand it is also not logical to qualify privatisation that lasts 20 years as a sign of shock therapy. On the contrary, this means that Slovenia privatised even more gradually than suggested in the model.

Under the neoclassical gradualist theory, institutions should be created in a joint collaborative fashion between market and state forces. The process should be 'gradual, natural, organic and voluntary' as opposed to top-down, allowing for the dissolution of ineffective institutions and the evolutionary strengthening of effective institutions (Kolodko, 2000, p. 274; Kornai, 1992, p. 160). The development of formal and informal institutions should take place throughout the whole transition period (Marangos, 2005a, pp. 276-279).

According to Sachs and Pleskovic, Slovenia had already begun to reform its institutional structure before the formal transition period started. For example, the Privatisation Agency and the Development Fund were established by the state in 1990 (Sachs and Pleskovic, 1994, p. 206). In 1991, Slovenia developed a number of new laws in order to establish economic institutions (Sachs and Pleskovic, 1994, p. 199). It appears that Slovenia did develop its formal institutions throughout the transition period and began development before the official transition beginning. However, near the end of the transition, institutional reform was slowing down, and this can be seen by the negative assessment of its institutions at the beginning of the EU accession. This suggests a slight deviation from the gradualist model.

The neoclassical gradualist model states that companies should face hard budget constraints from year three. An independent central bank should also be established during the third year of the transition (Marangos, 2005a, p. 286) mainly to control inflation. The Bank of Slovenia, the state's central bank, was established during the first year of transition. This is much earlier than the suggestion of the gradualist model and is actually identical to the shock therapy model. In terms of budget constraints, there is general agreement that soft budget constraints did exist, particularly at the beginning of transition.

Slovenia appeared to allow soft budget constraints for most companies, therefore, deviating significantly from the gradualist model. Towards the later phase of transition (nearing year 6), farmers faced increasingly harder budget constraints, 
but these too were compensated by comparatively large operational faming subsidies (slight deviation from the model).

The neoclassical gradualists believe, similarly to the shock therapy model, that the tax structure should be neutral (i.e., regressive, not progressive) and the government budgets should be balanced (Marangos, 2006, p. 145). According to Marangos, a tax system should be put into place within the first two years of transition (as opposed to the shock therapy prescription of 1 year), and budgets should be balanced during the whole transition period (Marangos, 2005a, p. 286).

According to the World Bank indicator 'Central government deficit and financing (\% of GDP) cash surplus/deficit', Slovenia's budget deficit rarely dropped below $2 \%$ of its GDP. A large budget deficit of $8.3 \%$ was recorded in 1995, after which the budget deficit remained between $1 \%-4 \%$. The Slovenian tax system was formed in 1990, when personal income taxes and corporate income taxes were introduced (Majcen, Verbič, Bayar, and Čok, 2009, p. 1). The income tax was initially very progressive. This system was modified in 2004, when the number of tax brackets was reduced to a total of 5 , and the lowest marginal tax rate was reduced from $17 \%$ to $16 \%$ (Klun, 2009, p. 223). The VAT system was adopted only in 1999 . This demonstrates that changes took place in taxation throughout the whole transition period, and the tax system was not set up within 2 years as the gradualist model prescribes.

The neoclassical gradualists believe that a pegged exchange rate should be used initially, after which a flexible floating exchange rate should be established in the $9^{\text {th }}$ or $10^{\text {th }}$ year (Marangos, 2006, p. 145). They also supported the idea of conditional foreign aid during the whole transition process. Tariffs are allowed and supported during the first 8 years of transition, after which these should be gradually removed (Marangos, 2006; Stiglitz, 2002; Dewatripont and Roland, 1992).

Slovenia established its own currency the tolar in 1991, similarly to Estonia, and it bypassed the pegged exchange rate step and started using the floating exchange rate mechanism from the beginning (Feldmann, 2006, p. 846). Similarly to Estonia, Slovenia acted against the advice of the IMF in setting up its own currency so quickly. Accordingly, Slovenia deviated clearly from the gradualist model, in skipping the 9-10 years of advised pegged exchange rate. In this respect, Slovenia was even more rapid in its reforms than even what the shock therapy model would expect.

To summarise, although Slovenia followed the gradualist model in maintaining some tariffs during the first 8 years of transition, it dropped more than $50 \%$ of its tariffs within the first 6 years. This suggests a significant deviation from the gradualist model's advice of holding tariffs high for 9-10 years.

In terms of foreign borrowing, Slovenia took loans from the IMF and WB, beginning only in 1993. This marks a slight deviation from the gradualist model.

The neoclassical gradualist model expects a wider safety net to be available for all residents than it is expected in the shock therapy model, but one that would be available for a limited amount of time to prevent dependence (Marangos, 2006, p. 146). Compared to the shock therapy model, private providers should be allowed on the market after year 3 of transition. 
Slovenia was noted to have maintained a comparatively large social safety net in place after transition. For example, its unemployment and poverty rates were both below the EU average, which is unusual for a transitioning country. Similarly, its expenditure as a percentage of GDP was comparable to the EU average, again unusual for a transitioning country (Šušteršič, 2009, p. 270). Feldmann has also indicated on the overall "generous redistribution, public works, and retraining and welfare programs” (Feldmann, 2006, p. 846).

In terms of using private providers of welfare, Slovenia has made significant progress in the privatisation of social welfare, especially in health care. The health care reform in 1992 introduced an additional, voluntary private health insurance pillar, "which almost became quasi-mandatory as its coverage became nearly universal" (Mrak, Rojec and Silva-Jauregui, 2004). Therefore, Slovenia deviated slightly in allowing its private providers to enter the market a little earlier (year 2 as opposed to 3) of the transition process.

To conclude: out of a total of 16 reform items in Slovenia, eleven deviated significantly from the shock therapy model, five deviated slightly and no reform items matched the gradualist model. A corresponding comparison of 15 Estonian reforms to the gradualist model showed that ten reform items deviated significantly, four deviated slightly and one matched the model. This suggests that the Slovenian example did not reflect the gradualist model particularly well, however, it did not reflect the shock therapy model particularly well either.

\section{ANALYSIS: ARE ESTONIA AND SLOVENIA MATCHING THE THEORETICAL MODELS?}

According to the research results, on the first level of analysis both test cases yielded similar results, as $53 \%$ and $69 \%$ of the analysed reforms deviated significantly from the models they were supposed to symbolise; in addition, $25 \%-31 \%$ of the reform items deviated slightly from their ideal models, and only $0 \%-20 \%$ of reform items did not deviate from their ideal models. The summarised results indicated that the reforms undertaken in Estonia and Slovenia bear low resemblance to the theoretical models they are supposed to support (33\% and $16 \%$ ).

The similarity with which the reforms in Estonia and Slovenia correspond to their opposing models ( $31 \%$ and $20 \%$, respectively) is even more striking. This makes Estonia look almost as good of an example of gradualism as it is an example of shock therapy, and Slovenia appears almost as good of an example of shock therapy as it is an example of gradualism.

On the second level of analysis (percentage match to the model), the score was calculated on the basis of alternative weights for each of the three categories, where significant deviations were given a small weight of $25 \%$ (as an inverse of ' $75 \%$ deviated', which is the median of ' $50 \%-100 \%$ deviated'). According to the research, overall results and conclusions remained similar: reforms in Estonia and Slovenia had low resemblance to the theoretical models they were supposed to illustrate $(48 \%$ and 
$37 \%$, respectively). Estonia and Slovenia once again showed high similarities to their so-called counterpart models ( $46 \%$ and $39 \%$, respectively). This suggests that regardless of which scoring system is used, Marangos' models are not able to accurately separate Estonia as shock therapy and Slovenia as gradualism. The alternative possibility is that Marango's model is generally accurate, but CEE reforms in 1991-2000 were exceptionally similar when evaluated on a broader scale.

On the third level of analysis, which targeted 14 reform elements, each rated independently by asking, 'Does this reform element correctly identify that Estonia looks more like shock therapy, and Slovenia more like gradualism?' (scored +1 ) or, 'Does this reform element make Estonia look more like gradualism and Slovenia more like shock therapy?' (scored -1). The total aggregate score for the 14 reform elements was -1.5 . This suggests that the reform elements are slightly more likely to classify the country cases into the 'wrong' model, but overall they have very little power to differentiate the Estonian and Slovenian cases into any model.

As the comparison shows, there were only seven instances (out of 62) when the actual practice matched the model within a $25 \%$ error margin. Most of these describe Estonia, where three items were well matched with shock therapy (income policy, tariffs, foreign aid) and three to gradualism (independent central bank, foreign borrowing, and foreign aid).

Five out of 16 reform items proved to be explanatory in deciding whether a country's case is more similar to the shock therapy or gradualist model. The remaining ten items provided no additional discriminatory power. The five most explanatory variables were: price deregulation (the analysis of which portrayed Estonia as slightly more inclined towards shock therapy), income policy (portrayed Estonia as slightly more shock therapy biased and Slovenia as slightly more gradualist), independent central bank (portrayed Estonia as significantly more gradualist and Slovenia as significantly more inclined towards shock therapy), tariffs (portrayed Estonia as significantly more shock therapy centred), and exchange rate (portrayed Slovenia as slightly more shock therapy biased).

Only one item out of 16 provided discriminant validity (income policy), in that it 'correctly' allocated Slovenia to the gradualist model and Estonia to the shock therapy model, despite slight deviations in both cases. The apparent failure of the other 15 items to provide any discriminate validity supports the general conclusions above and suggests that Marangos' models have low potential for correctly allocating the CEE country examples in 1991-2000 to the shock therapy and gradualist models.

It is not surprising that there are visible differences between theory and practice, particularly as theoretical assumptions are quite narrowly defined. Furthermore, the starting positions of the transition countries differed; what could be considered shock therapy (price liberalisation, for example) in some countries was part of initial conditions in another. In reality, the changes were a rather inconsistent combination of shock therapy and gradualism, both in the changes of economic systems or in economic policies, which depended very much on current political elites and randomly chosen foreign advisers. 
Table 1: Similarities and differences between the Estonian and Slovenian examples of transition, compared to the shock therapy and gradualist theories

\begin{tabular}{|c|c|c|c|c|c|}
\hline Indicator & $\begin{array}{l}\text { Estonia } \\
\text { vs shock } \\
\text { therapy }\end{array}$ & $\begin{array}{l}\text { Estonia } \\
\text { vs } \\
\text { gradualism }\end{array}$ & $\begin{array}{c}\text { Slovenia } \\
\text { vs } \\
\text { gradualism }\end{array}$ & $\begin{array}{l}\text { Slovenia } \\
\text { vs shock } \\
\text { therapy }\end{array}$ & Average \\
\hline $\begin{array}{l}\text { Number of reform items } \\
\text { that deviated significantly } \\
(>50 \%) \text { from the model }\end{array}$ & 8 & 9 & 11 & 10 & 10 \\
\hline $\begin{array}{l}\text { Number of reform items } \\
\text { that deviated slightly } \\
(25 \%-50 \%) \text { from the model }\end{array}$ & 4 & 4 & 5 & 4 & 5 \\
\hline $\begin{array}{l}\text { Number of reform items } \\
\text { that matched the model } \\
(<25 \% \text { deviation) }\end{array}$ & 3 & 3 & 0 & 1 & 2 \\
\hline $\begin{array}{l}\text { Percentage of reform items } \\
\text { that deviated significantly } \\
(>50 \%) \text { from the model }\end{array}$ & $53 \%$ & $56 \%$ & $69 \%$ & $67 \%$ & $61 \%$ \\
\hline $\begin{array}{l}\text { Percentage of reform } \\
\text { items that deviated slightly } \\
(25 \%-50 \%) \text { from the model }\end{array}$ & $27 \%$ & $25 \%$ & $31 \%$ & $27 \%$ & $29 \%$ \\
\hline $\begin{array}{l}\text { Percentage of reform items } \\
\text { that matched the model } \\
\text { ( }<25 \% \text { deviation) }\end{array}$ & $20 \%$ & $19 \%$ & $0 \%$ & $7 \%$ & $10 \%$ \\
\hline $\begin{array}{l}\text { Weighted matching score } \\
\left(=\text { significant deviations }^{*} 0\right)\end{array}$ & 0 & 0 & 0 & 0 & \\
\hline $\begin{array}{l}\text { Weighted matching score } \\
(=\text { significant deviations* } 0,5)\end{array}$ & 2 & 2 & 2,5 & 2 & \\
\hline $\begin{array}{l}\text { Weighted matching score } \\
\left(=\text { significant deviations }{ }^{*} 1\right)\end{array}$ & 3 & 3 & 0 & 1 & \\
\hline Total weighted score & 5 & 5 & 2,5 & 3 & \\
\hline $\begin{array}{l}\text { Number of reform items } \\
\text { (maximum weighted score) }\end{array}$ & 15 & 16 & 16 & 15 & \\
\hline $\begin{array}{l}\text { Percentage match to mo- } \\
\text { del total score/maximum } \\
\text { weighted score. }\end{array}$ & $33 \%$ & $31 \%$ & $16 \%$ & $20 \%$ & $24 \%$ \\
\hline
\end{tabular}

Source: Authors'compilation 
Marangos' model seems methodologically too general to diversify different cases of the CEE transition process, where most of the countries found themselves in a similar transition paradigm, based on values of 'Reagonomics' and 'Thatcherism'. In this transition model, the shock therapy appeared to be a basic matrix for values, and gradualism was forced by the practical circumstances, where despite political rhetoric countries needed similar reforms, which were in most cases possible within a similar timeframe.

Accordingly, the conceptual model and operationalisation used by Marangos provides more theoretical clarity than practical ability to explain the transition process logic in practical testing. In the cases of Estonia and Slovenia, the weakness of Marangos' model appeared in its disability to adapt to a starting situation, where the first reforms were conducted inside the federal union but continued later independently. This additional variable caused a situation, where both states were restricted by the central authorities to conduct key reforms in the first years of transition (currency reform, privatisation, etc.). As a result, test states received numerous minus points in terms of Marangos' checklist, since they were unable to conduct the necessary reforms according to their ideal model. Accordingly, in this aspect both concepts and their criteria need further development to be useful in practical testing, as also upcoming transition processes may occur in former federal unions.

\section{CONCLUSIONS}

This article has had two main goals, closely interlinked with each other. The first task was to analyse whether the reform paths undertaken by Estonia and Slovenia followed the theoretical concepts of 'shock therapy' and 'gradualism', the models the states are often symbolising in theoretical debates. The second task was to evaluate the ability of the theoretical models to correctly allocate the classical country examples to the shock therapy and gradualist models.

The study results related to the first question indicated that most of the reforms $(50 \%-70 \%)$ in Estonia and Slovenia deviated significantly from the ideals set by the theoretical models. A more complex analysis showed that Estonia corresponded to the shock therapy model by $33 \%$ and the gradualist model by $31 \%$. Slovenia corresponded to the gradualist model by $16 \%$ and the shock therapy model by $20 \%$. Only one reform out of sixteen correctly identified Estonia as representative of the shock therapy model and Slovenia as gradualist. This suggests that according to the theoretical model, Estonia appeared to be just as gradualist as it is a follower of shock therapy, and Slovenia is just as shock therapy inclined as it is gradualist. This conclusion brings into question the utility of the current 'models of transition' framework and calls for a substantially more nuanced one to replace it.

Of course, it is quite risky to argue that Estonian and Slovenian transition models are similar. There are many gradualist elements in the Estonian transition and other authors may have supporting arguments for opposite conclusions. The key question is the measurement methodology and validity that produced these 
unexpected results. Accordingly, either the measurement tools offered by Marangos were not sufficient for clear differentiation or the cases actually were similar. Marangos' model tends to sacrifice its explanatory ability to its simplicity and, in some aspects, mechanical logic.

This leads the authors to the conclusion that Marangos' models of shock therapy and gradualism have poor potential for correctly allocating the CEE country examples to the shock therapy and gradualist models. These transition models, which might be accurate to evaluate and explain a wider selection of transition cases, seem methodologically too general to diversify different cases of the CEE transition process, where most of the countries found themselves in a similar transition paradigm. In the Slovenian case, the criteria for Marangos' gradualist model were not fulfilled, while compared with the rest of the CEE countries during the period of 1991-2000, Slovenia was in many aspects one of the most careful, gradual and slowest reformers. In the case of Estonia, the criteria of Marangos' shock therapy model were also not met, and Estonia also did not follow the classical Polish shock therapy path, but at the same time, in many aspects Estonia's reforms were among the fastest and most radical in the CEE (privatisation, pension reform, currency reform, etc.)

What would be the probable solutions to overcoming the weaknesses of these theoretical models? Combining different models of transition would be one possible solution to raising the explanatory ability in practical cases. The current study additionally pointed out some critical aspects to be refined in future concepts of shock therapy and gradualism: a) a necessity to define central variables and initial conditions that influence the transition process; b) description and definitions of reforms (reform packages) that are best matched to the initial conditions and the overall logic of the model; c) mapping the specific trajectories, paths and patterns taken by countries in transition. With the next level concepts, more focus and consideration should be given to the relative importance, weighing or even omission of reform items.

\section{REFERENCES}

Avolio, C. (1995). Policies for Business in the Mediterranean Countries. Slovenia. Arco Felice (NA): Centre for Administrative Innovation in the Euro-Mediterranean Region

Balcerowicz, L. (1995). Socialism, Capitalism, Transformation. Budapest: Central European University Press.

Brendow, K. (2003). "Restructuring Estonia's oil shale industry: what lessons from restructuring the coal industries in Central and Eastern Europe?” Oil Shale, 20(3), 304-310.

Brown, W. S. (1993). "Economic transition in Estonia". Journal of Economic Issues, 27(2), 493-503.

De Melo, M., Denizer, C., Gelb, A., Tenev, A., \& Tenev, S. (2001). "Circumstance and choice: The role of initial conditions and policies in transition economies". The World Bank Economic Review, 15(1), 1-31.

Dewatripont, M., \& Roland, G. (1992). "The virtues of gradualism and legitimacy in the transition to a market economy.” The Economic Journal, 102, 291-300. 
EBRD (1998). Transition Report 1998: Financial sector in transition. European Bank for Reconstruction and Development http://www.ebrd.com/downloads/research/transition/TR98.pdf.

EBRD (1999). Transition Report 1999: Ten years of transition. European Bank for Reconstruction and Development http://www.ebrd.com/downloads/research/transition/TR99.pdf.

EBRD (2003). Transition Report 2003: Integration and regional cooperation. European Bank for Reconstruction and Development http://www.ebrd.com/downloads/research/transition/TR03.pdf.

EBRD (2004). Transition Report 2004: Infrastructure. European Bank for Reconstruction and Development http://www.ebrd.com/downloads/research/transition/TR04.pdf.

EBRD (2005), Transition Report 2005: Business in transition. Available from http://www.ebrd.com/ downloads/research/transition/TR05.pdf.

Elenurm, T. (2004). "Estonian perspectives of international entrepreneurship”. In L. P. Dana (ed.), Handbook of Research on International Entrepreneurship, Google eBook: Edward Elgar Publishing, 370-382.

Estonian Memorandum of Economic Policies, (1992). http://www.eestipank.ee/sites/default/files/files/ EestiPank/imf/1996-1992/1992_6en.pdf.

Estonian Memorandum of Economic Policies, (1995) http://www.eestipank.ee/sites/default/files/files/ EestiPank/imf/1996-1992/1995_5en.pdf.

Feldmann, G. (2006), "Emerging Varieties of Capitalism in Transition Countries: Industrial Relations and Wage Bargaining in Estonia and Slovenia”. Comparative Political Studies, vol 39 (7), 829 . 854

Gillies, J., Leimann, J., \& Peterson, R. (2002). "Making a successful transition from a command to a market economy: The lessons from Estonia”. Corporate Governance: An International Review, 10(3), 175-186.

Gwartney, J., Lawson, R., \& Hall, J. (2012). “2012 Economic Freedom Dataset”, published in Economic Freedom of the World: 2012 Annual Report, 1-322

Hannula, H. (2000). "Enterprise restructuring in transition economies: ownership type and manufacturing development". In Effectiveness of the economic policy of the Republic of Estonia and the European Union. Proceedings of the VIII International scientific conference. (72-80). Mattimar.

Hansson, H. (1993). "Transforming an economy while building a nation: the case of Estonia”. UNUWIDER Working Papers, 113.

Hinnosaar, M. (2003). “Minimum wage in Estonia when joining the European Union.” Eesti majanduspoliitika teel Euroopa Liitu [Estonian economic policy on the way to European Union], 329-336.

Hobdari, B., Jones, D. C., \& Mygind, N. (2009). „Capital investment and determinants of financial constraints in Estonia". Economic Systems, 33(4), 344-359.

Istenic, C. M. (1998). "Privatization of health care in Slovenia". Croatian Medical Journal, 39, 288297.

Klun, M. (2009). "Pre-filled income tax returns: Reducing compliance costs for personal income taxpayers in Slovenia". Financial Theory and Practice, 33(2), 219-233.

Kolodko, G. W. (2000). "Transition to a market and entrepreneurship: the systemic factors and policy options". Communist and Post-Communist Studies, 33(2), 271-293.

Kornai, J. (1992). “The principles of privatization in Eastern Europe”. De Economist, 140(2), 153-176.

Lesser, B (2000). BALT-ECON 2000: Economic Policy and Reform in Estonia, Latvia and Lithuania, 1992 to 2000 and Beyond. Halifax: BEMTP.

Lipton, D., \& Sachs, J. (1990). "Creating a market economy in Eastern Europe: the case of Poland". Brookings Papers on Economic Activity, 1, 75-133.

Majcen, B., Verbið, M., Bayar, A., \& \ok, M. (2009). “The income tax reform in Slovenia”. Eastern European Economics, 47(5), 5-24.

Marangos, J. (2002). "The political economy of shock therapy". Journal of Economic Surveys, 16(1), 41-76.

Marangos, J. (2005a). "A political economy approach to the neoclassical gradualist model of transition”. Journal of economic surveys, 19(2), 263-293. 
Marangos, J. (2005b). "Alternative paths to the transition process". International Journal of Social Economics, 32(4), 307-324.

Marangos, J. (2006). "Was there an optimum model of transition?" Global Business and Economics Review, 8 (1), 133-160.

Marangos, J. (2007). “The shock therapy model of transition”. International Journal of Economic Policy in Emerging Economies, 1(1), 88-123.

Mencinger, J. (2004). "Transition to a national and a market economy: a gradualist approach". in Mrak, M., Rojec, M., \& Silva-Jauregui, C. (2004). Slovenia: From Yugoslavia to the European Union. World Bank Publications, 67-82.

Mencinger, J. (2006). "Privatization in Slovenia". Slovenian Law Review, 3, 65.

Mrak, M., Rojec, M., \& Silva-Jauregui, C. (2004). Slovenia: From Yugoslavia to the European Union. World Bank Publications, 67-82.

Noorkõiv, R., Orazem, P. F., Puur, A. \& Vodopivec, M. (1997). “How Estonia's economic transition affected employment and wages (1989-95)". Policy Research Working Paper 1837, World Bank Publications, 1-35

Pomerants, M. (1998). "Proportional versus progressive income tax in Estonia”. In B. Lesser (Ed.) Baltic economic case studies, Vol. 3, Economic policy issues in Estonia, Latvia and Lithuania. Halifax: Baltic Economic Management Training Program, 47-58

Rindzeviciute, E (2004) “Contemporary change in Estonia”, Baltic and East European Studies 4, The Centre for Baltic and East European Studies (CBEES), Södertörn University, 1-88

Roland, G. (2000). Transition and Economics: Politics, Markets and Firms. (MIT press).

Sachs, J. (1995). "Reforms in Eastern Europe and the former Soviet Union in light of the East Asian experience". Journal of the Japanese and International Economies, 9(4), 454-485.

Sachs, J., \& Pleskovic, B. (1992). "Currency reform in Slovenia: the tolar standing tall” Transition 3(8), 6-8.

Sakkeus, J. (1998). "Foreign direct investment in Estonia". In B. Lesser (Ed.) Baltic Economic Case Studies, Vol. 3, Economic policy issues in Estonia, Latvia and Lithuania. Halifax: Baltic Economic Management Training Program, 3-22

Smith, S., Cin, B-C. \& Vodopivec, M. (1997). "Privatization incidence, ownership forms, and firm performance: evidence from Slovenia”. Journal of Comparative Economics, 25(2), 158-179.

Staehr, K. (2004). "Economic transition in estonia. Background, reforms and results, in Rindzeviciute. E. (ed): Contemporary Change in Estonia. Baltic and East European Studies, 4, The Centre for Baltic and East European Studies (CBEES), Södertörn University, 37-67.

Stiglitz, J. (2002). Globalisation and its Discontents, London: Penguin.

Šušteršič, J. (2009). "Endogenous gradualism and the Slovenian puzzle", China Economic Review, 20(2), 265-274.

Terk, E. (1999). Erastamine Eestis: ideoloogia, läbiviimine, tulemused. Eesti tulevikuuuringute instituut.

Terk, E. (2000). Privatisation in Estonia: Ideas, Processes, Results. Estonian Institute for Future Studies.

Veebel, V., \& Loik, R. (2012). Estonia: Life in Post-Communist Eastern Europe after EU Membership. Routledge, Taylor and Francis Group.

Veebel, V., \& Kulu, L. (2014) "Against the political expectations and theoretical models: how to implement austerity and not to lose political power", Baltic Journal of Economics, 14 (1-2), 2-16.

White, S., Batt, J., \& Lewis, P. G. (2007). Developments in Central and East European Politics. United States: Duke University Press Books. 